\title{
The contribution of pubertal development to performance scores in high-level rhythmic gymnasts
}

\author{
Tijana Purenović-Ivanovićc ${ }^{1, *}$, Ružena Popović ${ }^{1}$, and Lidija Moskovljević ${ }^{2}$ \\ ${ }^{I}$ Faculty of Sport and Physical Education, University of Niš, Niš, Serbia; and ${ }^{2}$ Faculty of Sport and Physical Education, \\ University of Belgrade, Belgrade, Serbia
}

Copyright: (c) 2017 T. Purenović-Ivanović et al. This is an open access article licensed under the Creative Commons Attribution License (http://creativecommons.org/licenses/by/4.0/).

\begin{abstract}
Background: Puberty is a central process in the complex set of changes that constitutes the transition from childhood to adolescence. This period of maturation is characterized by a growth spurt which affects virtually the whole skeleton and muscles and thus affecting children's motor performance. Objective: The present study investigated the role of pubertal status in predicting success in rhythmic gymnasts' (RGs) performance. Methods: One hundred and twenty-six national- and international-level RGs (age: $11.95 \pm 3.09$ years, body height: $147.76 \pm 14.61 \mathrm{~cm}$, body mass: $37.75 \pm 11.72 \mathrm{~kg}$, BMI: $16.79 \pm 2.26 \mathrm{~kg} / \mathrm{m}^{2}$, menarcheal age: $13.57 \pm 1.18$ years, training experience: $5.88 \pm 2.79$ years), divided into five age group categories, volunteered to participate in the study. A self-assessment was used for the estimation of the stages of sexual maturity of their breasts and axillary hair development (i.e. Tanner method), whereas the data on RGs menarche were collected by the means of interviewing. Results: Regression analysis showed that axillary hair development was the only independent parameter that had a positive influence on RGs' performance scores ( $b=1.693, p=.03$, advanced RGs), but overall RGs' pubertal development had a statistically significant influence on their performance $\left[R=.37, R^{2}=.14, F(3,122)=6.475, p<.001\right]$, with the explanation of participants' competitive/performance score (Success) in Rhythmic Gymnastics (RG) by 14\% of variance. Conclusion: This research indicates that RGs' athletic performance can be predicted by parameters of pubertal development, but not that well (it explains the Success by $14 \%$ of variance), and RGs' axillary hair development is a significant predictor of RG performance. In the group of pubertal RGs the established negative relations between the three examined pubertal development parameters and the performance scores could indicate that late maturation is desirable in RG.
\end{abstract}

Keywords: rhythmic gymnastics, sexual maturity, age categories, regression analysis

\section{Introduction}

Pubertal development signals the beginning of adolescence and it is characterized by rapid physical growth, large increases in hormonal levels, and the appearance of secondary sexual characteristics (Petersen \& Taylor, 1980 in Dubas, Graber, \& Petersen, 1991). It is a period of visible physical changes, such as adolescent growth spurt, breasts enlargement (i.e. thelarche), pubic hair development (i.e. pubarche) and axillary hair development (i.e. adrenarche) and the onset of menarche (i.e. first menstruation). The growth spurt, i.e. the peak development in girls starts, on average, at around the age of 9 and stabilises around the age of

* Address for correspondence: Tijana Purenović-Ivanović, Faculty of Sport and Physical Education, University of Niš, Čarnojevića 10a, 18000 Niš, Serbia. E-mail: tijanapurenovic@gmail.com
13 (Gallahue \& Ozmun, 2005) and it affects virtually all dimensions of the skeleton and muscles. The evolution of motor and physical performance in childhood is strongly associated with the growth processes and maturation (Ré, Bojikian, Teixeira, \& Böhme, 2005), the period in which young people experience an abrupt increase in their body composition. The fitness peak happens when a girl begins to reach the greatest magnitude of her growth during the pubertal period (Ulbrich et al., 2007). The research conducted by Guedes and Guedes (1993) demonstrated the annual increase in girls' performance between the age of 7 and 14, followed by the period of stabilisation. Also, the increase of aerobic capacity maturation has a significant influence (Freitas et al., 2003).

Individual sports exert a unique influence on biological maturation which is preconditioned by heterogeneity of the sport-specific demands of training and the 
stage of growth and sexual maturation of the individual athlete (Theodoropoulou et al., 2005). Depending on the specificity of training, biological maturation undergoes changes, delaying or advancing the process of biological development (Pinto Júnior, de Sousa, Gaya, \& Henriques Alves, 2012). The pubertal development in girls active in high-intensity rhythmic gymnastics (RG) is slower than in untrained girls (Tillmann et al., 2014). $\mathrm{RG}$, with the variety of exercises, affects the whole locomotor system and develops motor skills quite effectively (Lanaro Filho \& Böhme, 2001). All those motor skills depend on the metabolic support system, central nervous system, and many other systems which can be affected by biological maturation. According to the study conducted by Hespanhol, de Arruda, Prates, and Mathias (2008), biological maturation is a factor that directly influences the cognitive and motor development of children and young people, enabling them to perform more complex tasks with greater dexterity. Young people, particularly those who are in the maturational pubertal stage experience difficulties in making standard refined movements for which their growth spurt is to blame due to the direct influence it has on the motor pattern execution (Gallahue \& Ozmun, 2005; Linhares et al., 2009).

The term performance refers to determining the physical form, technique and psychological strength with maximum efficiency that one gymnast or a group can acquire. Optimal performance is the result of a complex interaction of several factors (Claessens, Lefevre, Beunen, \& Malina, 1999), and the growth and maturity characteristics of an athlete, to a large extent, affect their performance (Georgopoulos et al., 1999; Malina, Bouchard, \& Bar-Or, 2004; Pinto Júnior et al., 2012). The main question that this study deals with is: how well can rhythmic gymnasts' (RGs) performance be predicted from pubertal development parameters? The aim of this study was to evaluate pubertal development in young high-level RGs of different age categories and to determine its potential influence on the performance scores.

\section{Methods}

\section{Participants}

One hundred and twenty-six RGs, divided into five age categories ( 22 beginners, aged 7-9 years; 38 intermediate, aged 9-12 years; 26 advanced, aged 12-14 years; 25 juniors, aged 14-16 years; 15 seniors, aged 16 years and older), volunteered to participate in this crosssectional study. All of the participants are individual competitors at national and/or international level in the "A" and "B" program (Table 1), with their training experience ranging from 6 months to 14 years, and with 10 to 16 hours of training per week.

\section{Ethical considerations}

The study protocol was approved by the Ethics Committee of the Faculty of Sport and Physical Education, University of Niš, Serbia (No. 04-610). Written requests were promptly sent to the Expert Committee of the Gymnastics Federation of Montenegro, as well as to the Gymnastics Federation of Serbia, and, after being informed about the study, its scientific value and multiple benefits, and after informed consents were signed by gymnasts, i.e. their legal representatives, approvals were given for the testing to be conducted during the $6^{\text {th }}$ Montenegro Cup in 2013 (Budva, Montenegro), and during the 2014 National Championships (Belgrade, Serbia). All testing was performed in accordance with the ethical standards of the Helsinki Declaration (World Medical Association, 2002).

\section{Measures and procedures}

The first testing was conducted at the end of June 2013 in Budva (Montenegro), when 42 internationallevel gymnasts were tested. During the 2014 National

Table 1

Distribution of study participants according to age category, program and country of competition

\begin{tabular}{lccc}
\hline Age categories & $\begin{array}{c}6^{\text {th }} \text { Montenegro Cup 2013 } \\
\text { (Budva, Montenegro) }\end{array}$ & $\begin{array}{c}2014 \text { National Championships } \\
\text { (Belgrade, Serbia) }\end{array}$ & Total \\
\hline Beginners & $6 \mathrm{~A}+3 \mathrm{~B}$ & $0 \mathrm{~A}+13 \mathrm{~B}$ & $6 \mathrm{~A}+16 \mathrm{~B}=22$ \\
Intermediate & $5 \mathrm{~A}+13 \mathrm{~B}$ & $4 \mathrm{~A}+16 \mathrm{~B}$ & $9 \mathrm{~A}+29 \mathrm{~B}=38$ \\
Advanced & $2 \mathrm{~A}+7 \mathrm{~B}$ & $5 \mathrm{~A}+12 \mathrm{~B}$ & $7 \mathrm{~A}+19 \mathrm{~B}=26$ \\
Juniors & $1 \mathrm{~A}+5 \mathrm{~B}$ & $12 \mathrm{~A}+7 \mathrm{~B}$ & $13 \mathrm{~A}+12 \mathrm{~B}=25$ \\
Seniors & - & $7 \mathrm{~A}+8 \mathrm{~B}$ & $7 \mathrm{~A}+8 \mathrm{~B}=15$ \\
Total & $14 \mathrm{~A}+28 \mathrm{~B}=42$ & $28 \mathrm{~A}+56 \mathrm{~B}=84$ & $42 \mathrm{~A}+84 \mathrm{~B}=126$ \\
\hline
\end{tabular}

Note. $\mathrm{A}=$ "A" program (this program is totally in accordance with the FIG Code of Points); $\mathrm{B}=$ "B" program (this program is less demanding than an "A" program). 
Championships held in Belgrade (Serbia) on October $25^{\text {th }}$ and $26^{\text {th }}$, the second testing was performed and it included 84 Serbian gymnasts. Both competitions were organized under the FIG rules for the current Olympic cycle (2013-2016).

The study protocol included a non-invasive clinical investigation as well as the interviewing of the participants, and all the measurements and other data were taken by the authors. The parameters evaluated in the clinical investigation included body height and body mass measurements as well as the assessment of pubertal development. The Martin anthropometer was used to obtain the RGs' body height (in $\mathrm{cm}$ ), while body mass (in $\mathrm{kg}$ ) and body mass index (BMI, in $\mathrm{kg} / \mathrm{m}^{2}$ ) were assessed with a tetrapolar bioelectrical impedance device, Omron BF511 (Omron, Kyoto, Japan). RGs' pubertal development was estimated by a somatoscopy, i.e. Tanner method (Tanner, 1962), which implied the participants' self-assessment: standardized figure drawings depicting Tanner's sexual maturation stages of breast development were shown to the participants, and they were asked to rate it (from B1 to B5, where B1 is prepuberty, B2 to B4 is puberty, and B5 is postpuberty). Data on RGs' age, menarche (in years), axillary hair development (from $\mathrm{AH} 1$ to $\mathrm{AH} 3$, where $\mathrm{AH} 1$ is prepuberty, $\mathrm{AH} 2$ is puberty, and $\mathrm{AH} 3$ is postpuberty) and years of training experience were collected by the means of interviewing the participants.

The criterion, i.e. dependent variable, was the participant's competitive/performance score (Success), which can range from 0.0 to 20.0 points, according to the Code of Points (Fédération International de Gymnastique, 2013). Given the present differences between the five age categories (the youngest gymnasts do only exercise without apparatus) and "A" and "B" program requirements ("A" gymnasts do exercise with four apparatus, and "B" only with two), it was necessary to "equalize" the gymnasts. Therefore, in order to define the optimal criterion variable, the participant's performance score was the calculated mean value of the total of the points scored in the competition.

\section{Statistical analysis}

The data analysis was performed using the IBM SPSS software (Version 21.0; IBM, Armonk, NY, USA). Descriptive statistics (Mean, $S D$, Range) were summarized for all variables. Normality was tested using the one-sample Kolmogorov-Smirnov test (K-S). A multiple regression analysis $[R$ - multiple correlation coefficient, $R^{2}$ - coefficient of determination of multiple correlation, $F-F$-test] was performed with the aim of determining the amount of to what extent the variance in RGs' pubertal development influenced their performance, and simple regression analysis $[r$ - Pearson correlation coefficient, $b$ - regression coefficient, $p$ - statistical significance] was used to ascertain which of the pubertal development parameters had independent value in predicting the success rate in RG performance. The level of statistical significance was set at $\alpha<.05$.

\section{Results}

The baseline characteristics of the sample in total, as well as the subsamples (age categories) are presented in Table 2. The descriptive statistics data of the subsamples' and total sample's pubertal development parameters are presented in Table 3. The senior RGs are all in puberty (menarche obtained, $\mathrm{B}>1, \mathrm{AH}>1$ ), and only one $(0.07 \%)$ is in post puberty (B5, $\mathrm{AH} 2)$. In the group of juniors the situation is a bit different: most of them are in puberty, and only one $(0.04 \%)$ is in prepuberty (absence of menarche, B1, AH1). When considering menarche, only 11 of juniors (44\%) are menarcheal. Most of the advanced RGs are in puberty, but $30.76 \%(n=8)$ are in prepuberty (absence of menarche, B1, AH1), and only five of them are menarcheal. In the group of intermediate RGs most of the girls are in prepuberty, and only eight of them (21.05\%) are in puberty $(B>1)$. None of them have started menstruating yet and there is an absence of axillary hair (AH1). In the group of youngest RGs there are not any signs of pubertal development yet. Kolmogorov-Smirnov test (Table 3) showed absence of normal distribution of almost all data in every age category, except the breast development of the advanced RGs $(p=.09)$ and length of period since menarche in the group of seniors $(p=.54)$.

The distribution of pubertal development according to chronological age is shown in Table 3. Mean values, based on cross-sectional individual data obtained at the time of examination, which represent the chronological age at a certain stage of pubertal development, are as follows: breast Tanner stage II $(n=16)$ occurred at the age of $11.51 \pm 1.13$; stage III $(n=32)$ occurred at age of $14.32 \pm 1.62$ (Range: 11.38-18.95 years); stage IV $(n=16)$ occurred at age of $16.44 \pm 2.07$ (Range: 13.4-20.34 years), and stage $\mathrm{V}$ was established only in the case of one senior gymnast (17.58 years). The reported age of axillary hair development is as follows: Tanner stage II $(n=46)$ occurred at age of $15.07 \pm 2.09$ (Range: $11.38-20.34$ years); stage III $(n=5)$ occurred at age of $14.11 \pm 1.68$ (Range: 12.7-16.66 years); stages IV and $\mathrm{V}$ were not recorded in this sample of RGs.

Multiple regression analysis revealed the existence of significant influence of the RGs' pubertal development on the dependent variable (Success) only when considering the sample in total $\left[R=.37, R^{2}=.14\right.$, 
Table 2

Baseline characteristics of the study participants

\begin{tabular}{|c|c|c|c|c|c|c|c|}
\hline & $\begin{array}{c}\text { Age } \\
\text { (years) }\end{array}$ & $\begin{array}{l}\text { Body height } \\
\text { (cm) }\end{array}$ & $\begin{array}{l}\text { Body mass } \\
\quad(\mathrm{kg})\end{array}$ & $\begin{array}{c}\text { BMI } \\
\left(\mathrm{kg} / \mathrm{m}^{2}\right)\end{array}$ & $\begin{array}{l}\text { Menarcheal } \\
\text { age (years) }\end{array}$ & $\begin{array}{l}\text { Training experi- } \\
\text { ence (years) }\end{array}$ & $\begin{array}{l}\text { Success } \\
\text { (points) }\end{array}$ \\
\hline \multicolumn{8}{|c|}{ Beginners $(n=22)$} \\
\hline Mean $\pm S D$ & $8.04 \pm 0.75$ & $128.39 \pm 5.73$ & $25.28 \pm 2.85$ & $15.31 \pm 1.03$ & - & $2.53 \pm 1.44$ & $7.18 \pm 1.15$ \\
\hline Range & $6.67-9.08$ & $120.1-139.3$ & $20.8-30.8$ & $13.6-18.7$ & - & $0.5-6.0$ & $4.55-8.75$ \\
\hline K-S (sig.) & .852 & .722 & .989 & .639 & - & .190 & .342 \\
\hline \multicolumn{8}{|c|}{ Intermediate $(n=38)$} \\
\hline Mean $\pm S D$ & $10.12 \pm 0.8$ & $139.93 \pm 5.96$ & $29.96 \pm 4.31$ & $15.24 \pm 1.28$ & - & $4.93 \pm 1.86$ & $7.92 \pm 1.47$ \\
\hline Range & $8.71-12.02$ & $125.1-151.4$ & $22.6-40.2$ & $12.7-18.9$ & - & $1.0-8.0$ & $4.4-10.38$ \\
\hline K-S (sig.) & .945 & .606 & .963 & .654 & - & .328 & .940 \\
\hline \multicolumn{8}{|c|}{ Advanced $(n=26)$} \\
\hline Mean $\pm S D$ & $12.25 \pm 0.89$ & $151.31 \pm 8.72$ & $38.99 \pm 8.01$ & $16.83 \pm 1.94$ & $\begin{array}{c}12.33 \pm 0.77 \\
(n=5)\end{array}$ & $5.73 \pm 1.95$ & $7.86 \pm 1.58$ \\
\hline Range & $10.57-13.8$ & $136.0-164.4$ & $25.5-53.2$ & $13.8-21.4$ & $11.5-13.5$ & $0.5-9.0$ & $4.3-10.45$ \\
\hline K-S (sig.) & .987 & .670 & .894 & .524 & .868 & .364 & .254 \\
\hline \multicolumn{8}{|c|}{ Juniors $(n=25)$} \\
\hline Mean $\pm S D$ & $14.53 \pm 0.74$ & $162.94 \pm 7.05$ & $48.61 \pm 6.16$ & $18.23 \pm 1.4$ & $\begin{array}{c}13.55 \pm 1.19 \\
(n=11)\end{array}$ & $8.0 \pm 1.56$ & $9.34 \pm 1.54$ \\
\hline Range & $13.3-15.82$ & $146.1-176.7$ & $31.0-62.7$ & $14.5-20.4$ & $11.58-15.5$ & $4.0-10.0$ & $6.06-11.38$ \\
\hline K-S (sig.) & .994 & .788 & .569 & .953 & .952 & .178 & .789 \\
\hline \multicolumn{8}{|c|}{ Seniors $(n=15)$} \\
\hline Mean $\pm S D$ & $17.53 \pm 1.37$ & $164.56 \pm 6.83$ & $55.51 \pm 4.91$ & $20.48 \pm 1.16$ & $\begin{array}{c}13.99 \pm 1.02 \\
(n=15)\end{array}$ & $9.23 \pm 2.47$ & $9.29 \pm 1.91$ \\
\hline Range & $16.16-20.34$ & $150.0-178.2$ & $47.4-67.0$ & $19.0-23.3$ & $13-16$ & $5.0-14.0$ & $5.53-11.83$ \\
\hline K-S (sig.) & .482 & .792 & .920 & .628 & .644 & .964 & .938 \\
\hline \multicolumn{8}{|l|}{ Total $(N=126)$} \\
\hline Mean $\pm S D$ & $11.95 \pm 3.09$ & $147.76 \pm 14.61$ & $37.75 \pm 11.7$ & $16.79 \pm 2.26$ & $\begin{array}{c}13.57 \pm 1.18 \\
(n=31)\end{array}$ & $5.88 \pm 2.79$ & $8.22 \pm 1.69$ \\
\hline Range & $6.67-20.34$ & $120.1-178.2$ & $20.8-67.0$ & $12.7-23.3$ & $11.5-16.0$ & $0.5-14.0$ & $4.3-11.83$ \\
\hline K-S (sig.) & .176 & .209 & $.012 *$ & $.017^{*}$ & .712 & .176 & .833 \\
\hline
\end{tabular}

$F(3,122)=6.475, p<.001]$, with the explanation of Success in RG by $14 \%$ of variance. Also, statistically significant relations between Success and each of the pubertal development variables were established $\left(r_{\mathrm{B}}=.334, r_{\mathrm{AH}}=.367, r_{\mathrm{MENS}}=.201\right)$. At the univariate level regression analysis revealed significant independent contribution of axillary hair development to the prediction of Success in the group of advanced RGs only $(p=.03)$, with positive relationship between this independent variable and the dependent one $(b=1.693)$.

\section{Discussion}

Considering the number of body systems that must interact (musculoskeletal, cardiovascular, respiratory, nervous, etc.), it is not surprising that athletic performance is one of the most complex and the most investigated human traits (Purenović-Ivanović, Popović, Bubanj, \& Stanković, 2016). However, when considering sports such as rhythmic gymnastics, body composition is one of the most important factors which influences RGs' athletic performance (Borrione et al., 2013). Namely, it is well known that RG is a discipline which requires RGs to be in good shape and to maintain a thin body type with the lowest possible body fat content. On the other hand, highly intense physical training, chronic stress, nutritional factors, as well as low body weight, and/or low body fat are established factors that could alter menstrual function (Georgopoulos et al., 1999; di Cagno et al., 2012). The detrimental effects of these factors have been proven and it is well known that they influence all aspects of puberty, 
Table 3

Pubertal development of national-and international-level RGs of different age categories

\begin{tabular}{|c|c|c|c|c|c|c|}
\hline & $\begin{array}{l}\text { Beginners } \\
(n=22)\end{array}$ & $\begin{array}{l}\text { Intermediate } \\
\quad(n=38)\end{array}$ & $\begin{array}{l}\text { Advanced } \\
(n=26)\end{array}$ & $\begin{array}{l}\text { Juniors } \\
(n=25)\end{array}$ & $\begin{array}{l}\text { Seniors } \\
(n=15)\end{array}$ & $\begin{array}{c}\text { Total } \\
(N=126)\end{array}$ \\
\hline \multicolumn{7}{|c|}{ B (stages: average value and numerical status) } \\
\hline Mean $\pm S D$ & $\begin{array}{l}1.0 \pm 0.0 \\
B 1=22\end{array}$ & $\begin{array}{c}1.21 \pm 0.41 \\
\mathrm{~B} 1=30, \mathrm{~B} 2=8\end{array}$ & $\begin{array}{c}2.15 \pm 0.93 \\
\mathrm{~B} 1=8, \mathrm{~B} 2=7, \\
\mathrm{~B} 3=10, \mathrm{~B} 4=1\end{array}$ & $\begin{array}{c}3.08 \pm 0.64 \\
\mathrm{~B} 1=1, \mathrm{~B} 2=1, \\
\mathrm{~B} 3=18, \mathrm{~B} 4=5\end{array}$ & $\begin{array}{c}3.8 \pm 0.56 \\
\text { B } 3=4, \mathrm{~B} 4=10, \\
\text { B5 }=1\end{array}$ & $2.05 \pm 11.15$ \\
\hline Range & $1-1$ & $1-2$ & $1-4$ & $1-4$ & $3-5$ & $1-5$ \\
\hline K-S (sig.) & - & $<.001^{*}$ & .093 & $.002 *$ & $.031^{*}$ & $<.001^{*}$ \\
\hline \multicolumn{7}{|c|}{ AH (stages: average value and numerical status) } \\
\hline Mean $\pm S D$ & $\begin{array}{c}1.0 \pm 0.0 \\
\mathrm{AH} 1=22\end{array}$ & $\begin{array}{c}1.0 \pm 0.0 \\
\mathrm{AH} 1=38\end{array}$ & $\begin{array}{c}1.58 \pm 0.64 \dagger \\
\mathrm{AH} 1=13, \\
\mathrm{AH} 2=11, \\
\mathrm{AH} 3=2\end{array}$ & $\begin{array}{c}2.0 \pm 0.41 \\
\mathrm{AH} 1=2, \\
\mathrm{AH} 2=21, \\
\mathrm{AH} 3=2\end{array}$ & $\begin{array}{c}2.07 \pm 0.26 \\
\mathrm{AH} 2=14 \\
\mathrm{AH} 3=1\end{array}$ & $1.44 \pm 10.57$ \\
\hline Range & $1-1$ & $1-1$ & $1-3$ & $1-3$ & $2-3$ & $1-3$ \\
\hline K-S (sig.) & - & - & $.011^{*}$ & $<.001^{*}$ & $<.001^{*}$ & $<.001^{*}$ \\
\hline \multicolumn{7}{|l|}{ MENS (years) } \\
\hline Mean $\pm S D$ & - & - & $0.13 \pm 0.36$ & $0.59 \pm 0.86$ & $3.53 \pm 1.66$ & $0.56 \pm 11.31$ \\
\hline Range & - & - & $0.0-1.44$ & $0.0-2.45$ & $0.46-7.17$ & $0.0-7.17$ \\
\hline K-S (sig.) & - & - & $<.001 *$ & $.040 *$ & .542 & $<.001^{*}$ \\
\hline
\end{tabular}

Note. $\quad \mathrm{B}=$ breast development; $\mathrm{AH}=$ axillary hair development; $\mathrm{MENS}=$ length of period since menarche; K-S (sig.) = significance of Kolmogorov-Smirnov test. $\uparrow$ Statistically significant influence on the Success $(p=.03)$. *Absence of normal distribution (significant at $p=.05)$.

including the initiation of pubertal development and its progression from Tanner stage II to Tanner stages IV and V as well as menarche (Theodoropoulou et al., 2005). It is clearly demonstrated that RGs exhibit a moderate but significant delay in pubertal development (Georgopoulos et al., 2002, 1999, 2001). Nevertheless, low body weight and the intensity of training remained the most predictive factors in triggering the onset of puberty in RGs.

It is widely considered that biological maturity influences physical fitness test performance, and children can be advantaged or disadvantaged in physical fitness tests by being more or less mature than their peers. In the study of Pinto Júnior et al. (2012) pubescent RGs achieved better results in the tests of lower and upper limb explosive strength, which the authors from the study of C. D. Silva, Goldberg, Teixeira, and Marques (2004) attributed to menarche, believing that its presence might be one of the reasons for achieving the best performance in the strength tests of the upper limbs, probably due to an increased lean body mass (Gaya, Gonçalves da Silva, Cardoso, \& Torres, 2002), and the increased recruitment of motor fibers (Júnior, Medeiros, Queiroz, \& Sousa, 2007 in Pinto Júnior et al., 2012; D. A. S Silva \& Oliveira, 2010; Veldre \& Jürimäe, 2003). On the other hand, in the study of Jones, Hitchen, and Stratton (2000) it was concluded that sexual maturity had a large influence on physical fitness measurements in boys but without such strong influence in girls. Ré et al. (2005) found that young in earlier maturational stages had a significant advantage in the measurements involving conditional capacities. All these facts mentioned above led us to the potentially important factor which could influence RGs' athletic performance, and that was pubertal development. Namely, since RGs are at risk of developing pubertal development irregularities and since there is an absence of studies aiming to determining a possible influence that pubertal development could have on their successfulness or relations to their performance, we saw the necessity of examining this issue in more detail.

Adrenarche, the production of adrenal androgens, generally occurs 1-2 years before the other hormonal changes of puberty (Warren \& Perlroth, 2001). However, the time of thelarche (breast development) and adrenarche (pubic and axillary hair development) are found nearly coincident in the study of Theodoropoulou et al. (2005), but variations are possible and they do occur (Frota \& Pioner, 2010). In our study there was a discrepancy between Tanner stage II of thelarche $(11.51 \pm 1.13$ years $)$ and adrenarche $(15.07 \pm 2.09$ years), which can be assigned to the fact that axillary instead of pubic hair development was examined. The delayed onset of breast and hair development is mainly influenced by low body weight (Theodoropoulou et al., 2005), but there are exceptions: in the study of Warren 
(1980) a delayed thelarche and a normal pubarche (pubic hair development) were found in ballet dancers although they were under high-energy drain and low diet intake. This implies that independent mechanisms are involved in triggering these aspects of pubertal development (Theodoropoulou et al., 2005). When speaking about the influence of thelarche and adrenarche on RGs' performance, significant relations were found $(r=.334$ and $r=.367$, respectively; $p<.05$ ), as well as the individual contribution of adrenarche to the prediction of Success, in the group of advanced RGs only ( $p=.03$ ), with positive relationship between this independent variable and the dependent one. When speaking about RGs' breast development, the delay in the development was noticeable just as the fact that it was strongly influenced by the level of competition (the higher level of competition, the more delayed was thelarche).

Along with thelarche and adrenarche delay, menarche is known to be delayed in girls who start high intensity training before puberty (Lindholm, Hagenfeldt, \& Ringertz, 1994). That is why late menarche is common among female athletes such as rhythmic gymnasts (Ávila-Carvalho, Klentrou, da Luz Palomero, \& Lebre, 2012; Ávila-Carvalho, Klentrou, da Luz Palomero, \& Lebre, 2013; Georgopoulos et al., 2002; Georgopoulos et al., 1999; Klentrou \& Plyley, 2003; Theodoropoulou et al., 2005) and no wonder $29.81 \%$ of the current RGs (older than 9 and younger than 16) were amenarcheal. Moreover, considering the fact that the mean age of recalled menarche was $13.57 \pm 1.18$ years (the youngest age of menarcheal gymnast was 11.5 and the oldest one 16), and almost one third of the tested RGs were at that time still amenarcheal, the final mean age of recalled menarche was expected to be much higher than the present recorded one. When comparing this study results with previously reported values of menarcheal age, what can be noticed is that the higher the competition level, the later the menarche onset occurred, and that causal relation has been confirmed so many times so far (Warren \& Perlroth, 2001). Even though, the significant influence of the menarche, i.e. length of period since menarche, on the RGs performance is missing, the significant relation cannot be denied $(r=.201, p=.02)$.

In terms of energy deficit combined with a reduction in adipose tissue, estrogen production is decreased and breast development and menarche are delayed. Those two factors, plus sports activity, are strong enough to influence pubertal development, sexual maturation, and its major event, the menarche (Georgopoulos et al., 1999; Frota \& Pioner, 2010). Actually, all sportsrelated parameters such as low body weight and low body fat independently contribute to the delay in pubertal progression (Georgopoulos et al., 2001). Namely, the earlier onset of training, the greater intensity of training and the increased number of competitions per year (i.e. elite level competitors) lead to a more pronounced delay in all aspects of pubertal development.

\section{Conclusion}

This study investigated the extent to which the pubertal status influenced RGs' performance scores, and the major findings were: 1) statistically significant influence $(p<.001)$ of the gymnasts' pubertal development parameters on the Success, and 2) statistically significant $(p=.03)$ independent contribution of axillary hair development to the prediction of Success in the group of advanced RGs. The results of this study indicate that RGs' athletic performance can be predicted by parameters of pubertal development, but not that well (it explains the Success by $14 \%$ of variance), and RGs' axillary hair development is marked as significant predictor of RG performance (with a positive relationship), but only in the group of advanced RGs. This could be due to the fact that the advanced RGs are the group of gymnasts that exhibited the earliest entry into puberty, i.e. the group with the youngest menarcheal age $(12.33 \pm 0.77$ years $)$, in comparison to the other older age categories: juniors (13.55 \pm 1.19 years) and seniors (13.99 \pm 1.02 years), and due to the fact that they just reached the pubertal peak. However, in the group of senior RGs, which 15 out of 15 girls were in puberty at the time of the research, the regression analysis revealed a negative relationship of all of the three examined pubertal development parameters with the performance scores, which could indicate that late maturation is desirable in RG.

To our knowledge, this is the first study examining the influence of rhythmic gymnasts' pubertal development on their performance scores. Also, this research takes into account every single age category, which is very important because such data are lacking, and it encompasses a representative sample of elite nonSerbian and top-level Serbian RGs. However, certain shortcomings of this study need to be pointed out. First, the cross-sectional design is limiting, and longitudinal studies are needed to fill in the gaps in knowledge related to sexual maturation and RGs' performance, whether observed pubertal development parameters' influence is maintained or gained during pubertal growth. Furthermore, the limitation is that by necessity we had to use self-reported rather than objective data of recalled menarche, breast and axillary hair development. Finally, the sample size is relatively small, and our data concern only high-level RG. 


\section{Acknowledgments}

This research is a part of a project of the Ministry of Science and Technological Development of the Republic of Serbia (no. 179019, head researcher Prof. R. Stanković). The authors would like to thank Ms. Vesna Radonić, the president of the Gymnastics Federation of Montenegro, the organizer of the $6^{\text {th }}$ Montenegro Cup 2013, the participating rhythmic gymnasts and coaches of the following RG clubs: "Allegro" (Banja Luka, Serbia), "Baltic flower" (Jelgava, Latvia), "Budva" (Budva, Montenegro), "Danilovgrad" (Danilovgrad, Montenegro), "Partizan" (Belgrade, Serbia), "Ryazan" (Ryazan, Russia), "Sinegoria" (Moscow, Russia), "Vijandi Sports School” (Vijandi, Estonia) and "Vladimir" (Vladimir, Russia). The authors would also like to extend their deepest gratitude to the Gymnastics Federation of Serbia and its esteemed president Mrs. Milena Reljin Tatić, the organizer of the 2014 National Championship, the rhythmic gymnasts and coaches of Serbian RG clubs: "Gymnastix" (Niš), "Palilula" (Belgrade), "Paraćin" (Paraćin), "Radnički" (Belgrade), "Ritam" (Belgrade), "Ritam-Pinki” (Belgrade), "Ritmix" (Novi Sad), and "TiM" (Belgrade), who made this study possible.

\section{Conflict of interest}

There were no conflicts of interest.

\section{References}

Ávila-Carvalho, L., Klentrou, P., da Luz Palomero, M., \& Lebre, E. (2012). Body composition profile of elite group rhythmic gymnasts. Science of Gymnastics Journal, 4, 21-32.

Ávila-Carvalho, L., Klentrou, P., da Luz Palomero, M., \& Lebre, E. (2013). Anthropometric profiles and age at menarche in elite group rhythmic gymnasts according to their chronological age. Science \& Sports, 28, 172-180.

Borrione, P., Battaglia, C., Fiorilli, G., Moffa, S., Tsopani, D., Piazza, M., ... Di Cagno, A. (2013). Body image perception and satisfaction in elite rhythmic gymnasts: A controlled study. Medicina dello Sport, 66, 61-70.

Claessens, A. L., Lefevre, J., Beunen, G., \& Malina, R. M. (1999). The contribution of anthropometric characteristics to performance scores in elite female gymnasts. Journal of Sports Medicine \& Physical Fitness, 39, 355-360.

di Cagno, A., Marchetti, M., Battaglia, C., Giombini, A., Calcagno, G., Fiorilli, G., ... Borrione, P. (2012). Is menstrual delay a serious problem for elite rhythmic gymnasts? Journal of Sports Medicine \& Physical Fitness, 52, 647-653.

Dubas, J. S., Graber, J. A., \& Petersen, A. C. (1991). The effects of pubertal development on achievement during adolescence. American Journal of Education, 99, 444-460.
Fédération International de Gymnastique. (2013). 2013-2016 Code of Points (Rhythmic Gymnastics). Lausanne, Switzerland: Author.

Freitas, D. L., Maia, J. A., Beunen, G. P., Lefevre, J. A., Claessens, A. L., Marques, A. T., ... Philippaerts, R. M. (2003). Maturação esquelética e aptidão física em crianças e adolescentes madeirenses [Skeletal maturity and physical fitness of children and youth from the Autonomous Region of Madeira]. Revista Portuguesa de Ciências do Desporto, 3, 61-75.

Frota, R. S., \& Pioner, R. S. (2010). O perfil de maturação biológica entre ginastas de alto rendimento de 9 a 14 anos de ginástica rítmica de três clubes da cidade de Porto Alegre [The biological maturity profile of elite rhythmic gymnasts aged 9 to 14 from three clubs in the city of Porto Alegre] [Monograph]. Revista da Graduação, 3(1).

Gallahue, D. L., \& Ozmun, J. C. (2005). Compreendendo o desenvolvimento motor: Bebês, crianças, adolescentes e adultos [Understanding a motor development: Babies, children, adolescents and adults]. São Paulo, Brasil: PHORTE.

Gaya, A., Gonçalves da Silva, G., Cardoso, M., \& Torres, L. (2002). Talento esportivo: Estudo de indicadores somato-motores na seleção para o desporto de excelência [Sport talent: Motor somatic indicators in the selection to sport of excellence]. Retrieved from http://portal.esporte.gov. br/arquivos/snear/talentoEsportivo/baseTeoricaTalentoEsportivoDesportoExcelencia.pdf

Georgopoulos, N. A., Markou, K. B., Theodoropoulou, A., Benardot, D., Leglise, M., \& Vagenakis, A. G. (2002). Growth retardation in artistic compared with rhythmic elite female gymnasts. Journal of Clinical Endocrinology \& Metabolism, 87, 3169-3173.

Georgopoulos, N. A., Markou, K. B., Theodoropoulou, A., Paraskevopoulou, P., Varaki, L., Kazantzi, Z., ... Vagenakis, A. G. (1999). Growth and pubertal development in elite female rhythmic gymnasts. Journal of Clinical Endocrinology \& Metabolism, 84, 4525-4530.

Georgopoulos, N. A., Markou, K. B., Theodoropoulou, A., Vagenakis, G. A., Benardot, D., Leglise, M., .... Vagenakis, A. G. (2001). Height velocity and skeletal maturation in elite female rhythmic gymnasts. Journal of Clinical Endocrinology \& Metabolism, 86, 5159-5164.

Guedes, D. P., \& Guedes, J. E. R. (1993). Crescimento e desempenho motor em escolares do município de Londrina, Paraná, Brasil [Growth and motor performance of schoolchildren from the city of Londrina, Paraná, Brazil]. Cadernos de Saúde Pública, 9(Suppl. 1), 58-70.

Hespanhol, J. E., de Arruda, M., Prates, J. M., \& Mathias, F. H. (2008). Associação entre maturação e desempenho do salto vertical em jovens voleibolistas [Maturity-associated variation in vertical jump performance of youth volleyball players]. Conexões, 6(3), 55-67.

Jones, M. A., Hitchen, P. J., \& Stratton, G. (2000). The importance of considering biological maturity when assessing physical fitness measures in girls and boys aged 10 to 16 years. Annals of Human Biology, 27, 57-65.

Klentrou, P., \& Plyley, M. (2003). Onset of puberty, menstrual frequency, and body fat in elite rhythmic gymnasts compared with normal controls. British Journal of Sports Medicine, 37, 490-494. 
Lanaro Filho, P., \& Böhme, M. T. S. (2001). Detecção, seleção e promoção de talentos esportivos em ginástica rítmica desportiva: Um estudo de revisão [Detection, selection and promotion of sports talents in rhythmic gymnastics: A review study]. Revista Paulista de Educação Física, 15, 154-168.

Lindholm, C., Hagenfeldt, K., \& Ringertz, B. M. (1994). Pubertal development in elite juvenile gymnasts: Effects of physical training. Acta Obstetricia et Gynecologica Scandinavica, 73, 269-273.

Linhares, R. V., Matta, M. D. O., Lima, J. R., Dantas, P. M. S., Costa, M. B., \& Fernandes Filho, J. (2009). Efeitos da maturação sexual na composição corporal, nos dermatóglifos, no somatótipo e nas qualidades físicas básicas de adolescents [Effects of sexual maturation on body composition, dermatoglyphics, somatotype and basic physical qualities of adolescents]. Arquivos Brasileiros de Endocrinologia e Metabologia, 53, 47-54.

Malina, R. M., Bouchard, C., \& Bar-Or, O. (2004). Growth, maturation, and physical activity (2nd ed.). Champaign, IL: Human Kinetics.

Pinto Júnior, J. A. D., de Sousa, M. D. S. C., Gaya, A. C. A., \& Henriques Alves, J. V. D. M. (2012). Maturação biológica e desempenho físico de jovens atletas de ginástica rítmica [Biological maturation and physical performance of young athletes in rhythmic gymnastics]. Revista Brasileira de Ciência e Movimento, 20, 88-96.

Purenović-Ivanović, T., Popović, R., Bubanj, S., \& Stanković, R. (2016). Rhythmic gymnasts' somatotype: Is it a predictive factor for RG performance? Acta Kinesiologica, 10, 92-99.

Ré, A. H. N., Bojikian, L. P., Teixeira, C. P., \& Böhme, M. T. S. (2005). Relações entre crescimento, desempenho motor, maturação biológica e idade cronológica em jovens do sexo masculine [Relationship between physical growth, motor performance, biological maturation and chronological age in boys]. Revista Brasileira de Educação Física e Esporte, 19, 153-162.

Silva, C. D., Goldberg, T. B. L., Teixeira, A. S., \& Marques, I. (2004). O exercício físico potencializa ou compromete o crescimento longitudinal de crianças e adolescentes? Mito ou verdade? [Does physical exercise increase or compromise children's and adolescent's linear growth? Is it a myth or truth?]. Revista Brasileira de Medicina do Esporte, 10, 520-524.

Silva, D. A. S., \& Oliveira, A. C. (2010). Impacto da maturação sexual na força de membros superiores e inferiores em adolescents [Impact of sexual maturation on upper and lower limb strength on adolescents]. Revista Brasileira de Cineantropometria \& Desempenho Humano, 12, 144-150.

Tanner, J. M. (1962). Growth at adolescence (2nd ed.). Oxford, United Kingdom: Blackwell Scientific Publications.

Tillmann, V., Võsaberg, K., JürimParm, A. L., Saar, M., Jürimäe, T., Maasalu, K., ... Jürimäe, J. (2014). Serum leptin, ghrelin, and adiponectin levels in relation to body composition in rhythmic gymnasts entering into puberty: A 3-year follow-up study. Hormone Research in Pediatrics, 82(Suppl. 1), 161-162.

Theodoropoulou, A., Markou, K. B., Vagenakis, G. A., Benardot, D., Leglise, M., Kourounis, G., ... Georgopoulos, N. A. (2005). Delayed but normally progressed puberty is more pronounced in artistic compared with rhythmic elite gymnasts due to the intensity of training. Journal of Clinical Endocrinology \& Metabolism, 90, 6022-6027.

Ulbrich, A. Z., Bozza, R., Machado, H. S., Michelin, A., Vasconcelos, I. Q. A., Stabelini, A. N., ... Campos, W. (2007). Physical fitness in children and adolescents in different maturation stages. Fitness \& Performance, 6, 277-282.

Veldre, G. E., \& Jürimäe, T. (2003). Factor analysis of anthropometrical variables, somatotype components and sexual maturation signs of 12-15-year-old children. Papers on Anthropology, 12, 257-270.

Warren, M. P. (1980). The effects of exercise on pubertal progression and reproductive function in girls. Journal of Clinical Endocrinology \& Metabolism, 51, 1150-1157.

Warren, M. P., \& Perlroth, N. E. (2001). The effects of intense exercise on the female reproductive system. Journal of Endocrinology, 170, 3-11.

World Medical Association. (2002). World Medical Association Declaration of Helsinki: Ethical principles for medical research involving human subjects. Retrieved from http:// www.fda.gov/ohrms/dockets/dockets/06d0331/06D-0331EC20-Attach-1.pdf 